\title{
PHYSICOCHEMICAL COMPOSITION AND SENSORY ANALYSIS OF WHOLE JUICE EXTRACTED FROM GRAPES IRRADIATED WITH ULTRAVIOLET C ${ }^{1}$
}

\author{
TAÍSA CERATTI TREPTOW ${ }^{2}$, FERNANDA WOUTERS FRANCO ${ }^{3}$, LAURA GIZELE MASCARIN ${ }^{4}$, \\ LUISA HELENA RYCHECKI HECKTHEUER ${ }^{5}$,CLÁUDIA KAEHLER SAUTTER ${ }^{6}$
}

\begin{abstract}
Grape juice has been widely studied due to the presence of phenolic compounds and its beneficial effects on human health. Ultraviolet irradiation C (UV-C) can increase the content of phenolic compounds and anthocyanins and contribute to sensory acceptability. The aim of this study was to evaluate the effect of different doses of ultraviolet irradiation C (UV-C) on 'Trebbiano', 'Niagara Branca', 'Isabel' and 'Cabernet Sauvignon' grapes, as well as effect of the storage period. Juices were elaborated and evaluated for physicochemical analyses, and for the sensorial analysis in irradiated samples. In 'Niagara Branca' and 'Trebbiano' cultivars, storage and irradiation promoted few physicochemical alterations, and sensorially, irradiation reduced the intensity of flavor and color attributes. In juices from 'Isabel' and 'Cabernet Sauvignon' cultivars, the storage period led to the concentration of sugars and irradiation influenced physicochemical parameters and increased the intensity of aroma attribute at dose of $2 \mathrm{~kJ} \mathrm{~m}^{-2}$. Thus, UV-C irradiation contributes little for the improvement of white grape juices; however, it favors some sensory attributes in red grape juice, requiring further studies to elucidate the influence of UV-C irradiation on the phenolic and volatile composition of grape juice.
\end{abstract}

Index terms: Vitis labrusca, Vitis vinifera, abiotic elicitor, postharvest, total polyphenols, ordering test.

\section{COMPOSIÇÃO FÍSICO-QUÍMICA E ANÁLISE SENSORIAL DO SUCO INTEGRAL DE UVAS IRRADIADAS COM LUZ ULTRAVIOLETA DO TIPO C}

RESUMO -O suco de uva vem sendo amplamente estudado pela presença dos compostos fenólicos e seu efeito benéfico para saúde humana. A irradiação ultravioleta do tipo C (UV-C) pode aumentar compostos fenólicos, antociânicos e contribuir com a aceitabilidade sensorial. Este trabalho teve como objetivo avaliar no suco o efeito da aplicação de diferentes doses de irradiação ultravioleta do tipo C (UV-C) sobre as uvas 'Trebbiano', 'Niágara Branca', 'Isabel' e 'Cabernet Sauvignon', bem como o efeito do período de armazenamento. Os sucos foram elaborados e avaliados quanto às análises físico-químicas, e quanto à análise sensorial em amostras irradiadas. Nos sucos das cultivares 'Niágara Branca'e 'Trebbiano', o armazenamento e a irradiação promoveram poucas alterações físico-químicas, e sensorialmente a irradiação reduziu a intensidade dos atributos sabor e cor. Nos sucos das cultivares tintas 'Isabel' e 'Cabernet Sauvignon', o armazenamento levou à concentração de açúcares e a irradiação influenciou tanto os parâmetros físico-químicos quanto favoreceu o aumento da intensidade do atributo aroma na dose de $2 \mathrm{~kJ} \mathrm{~m}^{-2}$. Sendo assim, a irradiação UV-C pouco contribui para a melhoria dos sucos de uvas brancas, no entanto, favorece alguns atributos sensoriais nos sucos de uvas tintas, sendo necessários estudos mais amplos para elucidar a influência da irradiação UV-C na composição fenólica e volátil.

Termos para indexação: Vitis labrusca, Vitis vinifera, elicitor abiótico, pós-colheita, polifenóis totais, teste de ordenação.

\footnotetext{
1(Paper 273-15). Received December 08, 2015. Accepted July 07, 2016.

${ }^{2}$ Nutritionist, PhD in Food Science and Technology, UFSM, Avenida Roraima, 1000. E-mail: taisact@gmail.com

${ }^{3}$ Pharmacist, PhD Student in Food Science and Technology, UFSM. E-mail: fernandafranco8@hotmail.com

${ }^{4}$ Chemist, PhD Student in Food Science and Technology, UFSM. E-mail: lauragizele@gmail.com

${ }^{5} \mathrm{PhD}$ in Food Science and Technology, full teacher, Department of Food Science and Technology, UFSM. E-mail: luihrh@hotmail.com ${ }^{6} \mathrm{PhD}$ in Agronomy, assistant teacher, Departament of Food Science and Technology, UFSM. E-mail: cksautter@gmail.com
} 


\section{INTRODUCTION}

In Brazil, grape juice is made from American cultivars of Vitis labrusca species, due to consumer preference for aroma, color and flavor. Cultivars of Vitis vinifera species are preferentially used for the production of fine wines, as well as for the production of juice (CAMARGO; MAIA; RITSCHEL, 2010), especially 'Cabernet Sauvignon' cultivar (DUTRA et al., 2014).

Grape juice has been widely studied due to the presence of phenolic compounds and its potential beneficial effect on human health. The intake of foods rich in polyphenols has contributed to slow the onset of chronic and cardiovascular diseases and cancer (YAMAGATA; TAGAMI; YAMORI, 2015; RUIZ; HERNÁNDEZ, 2014; TANGNEY; RASMUSSEN, 2013). The main pathways of action of polyphenols are through their anti-inflammatory activity and antioxidant capacity (ANDROUTSOPOULOS, et al., 2010).

Grapes coming from Vitis vinifera and Vitis labrusca species are mainly different regarding the resistance to fungal diseases such as anthracnose, mildew and powdery mildew, as well as to climate adaptation and processing possibilities (PINTO et al., 2016; ÇETIN et al., 2011). However, when dealing with postharvest losses, both are highly perishable, leading to the need for the use of new technologies to reduce losses.

Ultraviolet irradiation C (UV-C) is widely known as abiotic elicitor due to its germicidal action in grapes especially in the control of fungal contamination (SCHUMPP et al., 2012, TYUNIN and KISELEV, 2016). This technology can also stimulate the secondary metabolism of plants, favoring the production of defense chemicals without leaving residues that could be a risk to human health (MARTI et al., 2014; PINTO et al., 2016; 50 SHEN et al., 2013).

In addition to its effect on the control of postharvest diseases in grapes, UV-C irradiation stimulates the production of phenolic compounds in fruits after 4-6 days stored at $20^{\circ} \mathrm{C}$ (CANTOS et al., 2002; SAUTTER et al). In wines produced with Vitis vinifera cultivars, better acceptance regarding the aroma of wines produced from irradiated 'Trebbiano' grapes was observed (BERTAGNOLLI et al., 2007).

Considering that the use of UV-C radiation can stimulate the production of bioactive compounds (TYUNIN; KISELEV, 2016), and that one of the major forms of grape consumption in Brazil is through juice (IBRAVIN, 2015), the importance of evaluating the physical and chemical parameters resulting from the application of this technology to grapes is justified.

In addition, there are only few studies on its use due the fact that it is a recent technology (MARTI et al., 2014; PINTO et al., 2016). Thus, the present study aimed to evaluate the postharvest effect of different doses of ultraviolet irradiation $\mathrm{C}$ (UV-C) on 'Trebbiano', 'Niagara Branca', 'Isabel' and 'Cabernet Sauvignon' grapes, as well as the effect of the storage period.

\section{MATERIAL AND METHODS}

Juice samples were produced with grapes from the Serra and Campanha Gaúcha regions in the 2011/12 harvest. 'Isabel' and 'Niagara Branca' cultivars were harvested in vineyards located in the municipality of Caxias do Sul - RS (29 $19^{\circ}$ ' $05^{\prime}$ " $\mathrm{S} ; 51^{\circ} 10^{\prime} 46^{\prime \prime} \mathrm{W}$ and $817 \mathrm{~m}$ altitude.). 'Cabernet Sauvignon' cultivar came from Dom Pedrito - RS ( $30^{\circ} 58$ ' $58^{\prime \prime} \mathrm{S}, 54^{\circ} 40^{\prime} 23^{\prime}$ " $\mathrm{W}$ and $141 \mathrm{~m}$ altitude.) 'Trebbiano' cultivar came from the city of Santana do Livramento - RS 72 ( $30^{\circ} 53$ ' 27 ' $\mathrm{S}$; 55 ${ }^{\circ} 31^{\prime}$ ' 58”' $\mathrm{W}$ and $208 \mathrm{~m}$ altitude).

Grape clusters were transported to the Núcleo Integrado de Desenvolvimento em Análises Laboratoriais (NIDAL), Universidade Federal de Santa Maria, and acclimated for 6 hours at $20^{\circ} \mathrm{C}$. Stems were then removed with a pair of scissors, kept with a peduncle and stored for 24 hours at $20^{\circ}$ $\mathrm{C}$ for healing of tissues.

The experiment was applied independently in 'Niagara Branca', 'Trebbiano', 'Isabel' and 'Cabernet Sauvignon' cultivars. The experimental design was the completely randomized consisting of the initial grape sample (without storage and without irradiation) and four UV-C irradiation treatments at doses $0,1,2$ and $3 \mathrm{~kJ} \mathrm{~m}^{-2}$ followed by five days of storage with four replicates per treatment. The experimental unit consisted of $500 \mathrm{~g}$ of grape clusters, originating 20 sample units yielding $480 \mathrm{~mL}$ of juice. The juice was analyzed for the physicochemical composition in the initial samples and in samples treated with UV-C irradiation. For sensory analysis, only juices from grapes treated with UV-C irradiation were analyzed.

The irradiation method used was that described in Sautter et al. (2008) with adaptations, according to Treptow (2012). The sample units were placed on reflective aluminum trough without overlapping clusters for exposure to UV-C radiation. Irradiation occurred at a distance of $29 \mathrm{~cm}$ from the source to the surface in an anti-reflective chamber 
with ultraviolet irradiation C (UV-C) (Phillips ${ }^{\circledR}$, model TUV15W-G15T8 Longe Life, power $15 \mathrm{~W}$ ) with air circulation at $25^{\circ} \mathrm{C}$ to deplete the ozone, thus avoiding a second elicitor. Irradiance of 3.048 $\mathrm{W} \mathrm{m}^{-2}$ at wavelength of $254 \mathrm{~nm}$ was measured using spectroradiometer (International Light ${ }^{\circledR}$, model RPS900). Doses were calculated by integrating exposure time and source irradiance, using the OringinTM version 5.0 package. Grape clusters received doses of $0,1,2$ and $3 \mathrm{~kJ} \mathrm{~m}^{-2}$ and remained stored in heated chamber at $20^{\circ} \mathrm{C}$ for 5 days for the development of the physiological response.

The storage time after the five-day UV-C irradiation was based on preliminary studies, where the best responses were found for the physicochemical parameters, which was also reported as the best period by researchers such as Cantos et al. (2002).

Juices were elaborated based on the method of Flanzy, with cold sulphurous maceration process described by Manfroi (1999). Juice was packed in 500 $\mathrm{ml}$ glass bottles, where soluble solids (SS) content was determined by refractometry at temperature of $20^{\circ} \mathrm{C}$. Titratable total acidity was determined according to methodology described by Amerine and Ough (1980), and the results were expressed as tartaric acid per 100 milliliters of juice (g 100 $\mathrm{mL}^{-1}$ ). The determination of total anthocyanins was performed by spectrophotometry, as described by Di Stefano (1989), with results expressed in grams of malvidin per 100 milliliters of juice $(\mathrm{g} 100 \mathrm{~mL}$ ${ }^{-1}$ ). Total polyphenols were determined according to method of Singleton and Rossi Junior (1965) and expressed in grams of gallic acid per 100 milliliters of juice $\left(\mathrm{g} 100 \mathrm{~mL}^{-1}\right)$. The determination of total, reducing and non-reducing sugars was carried out using the colorimetric method of Somogyi and Nelson (NELSON, 1944) and results were expressed in grams of glucose per 100 milliliters of juice ( $\mathrm{g}$ $\left.100 \mathrm{~mL}^{-1}\right)$.

Sensory analysis was carried out by applying the ordering test, in which each judge received four juice samples (referring to the different UV-C doses of $0,1,2$ and $3 \mathrm{~kJ} \mathrm{~m}^{-2}$ ) of each cultivar, ordering samples in decreasing order regarding color intensity, aroma and flavor (IAL, 2008).

Analyses were carried out at the Laboratory of Sensory Analysis, Departamento de Tecnologia e Ciência dos Alimentos and at the Núcleo Integrado de Desenvolvimento em Análises Laboratoriais, both at the Universidade Federal de Santa Maria - RS. The panel consisted of 60 untrained judges, and the analyses of juices from each cultivar were performed on alternate days, and each judge randomly received samples coded with three digits in the amount of 20 $\mathrm{mL}$ in transparent acrylic cup, forms to be filled, water and crackers for cleaning taste buds, and coffee for cleaning the smell, between samples. The research was approved by the Ethics Research Committee of the Universidade Federal de Santa Maria, under numbers: 23081.020467 / 2010-07 and CAAE: 0388.0.243.000-10.

Data obtained from physicochemical analyses were used to study two effects. The first effect was on storage between initial sample and the dose of $0 \mathrm{~kJ}$ $\mathrm{m}^{-2}$ as determined by Student's t-test $(\mathrm{p}<0.05)$. The second effect was of UV-C irradiation determined by the analysis of variance, followed by the Tukey test at $5 \%$ error probability. The statistical software used for both tests was Statistica ${ }^{\circledR}$ 9.0. The results of the sensory analysis for color, aroma and flavor attributes were analyzed using the Friedman test and the table of Newell and MacFarlane (MEILGAARD et al., 1987), considering 5\% error probability.

\section{RESULTS AND DISCUSSION}

The juice produced from non-irradiated 'Niagara Branca' grapes showed reduction in the concentration of total sugars during the five-day storage period (Table 1). However, when considering postharvest UV-C irradiation, it was observed that the dose of $3 \mathrm{~kJ} \mathrm{~m}^{-2}$ promoted a decrease in the content of non-reducing sugars and an increase in the content of reducing sugars (Table 1), indicating a probable homeostasis process, since there were no changes in total polyphenols in the same period. This has already been discussed by Shama and Alderson (2005), who showed that low-dose irradiation can stimulate vital processes within cells and trigger homeostasis.

In addition, sugars may represent components of the primary metabolism and be used as energy sources to maintain berries, or assist in the production of substances of the secondary metabolism, such as phenolic compounds (ALI et al., 2010; PINTO et al., 2016; PALA; TOKLUCU, 2013). According to Vermerris and Nicholson (2006), the precursors of phenolic compounds can be derived from the catabolic process of glycolysis.

The results of 'Niagara Branca' juice showed an increase in the concentration of total sugars at doses of 2 and $3 \mathrm{~kJ} \mathrm{~m}^{-2}$ (Table 1). Sensory analysis only showed a significant difference $(p<0.05)$ for flavor and color attributes of the juice at dose of $3 \mathrm{~kJ}$ $\mathrm{m}^{-2}$, presenting a lower intensity when compared to dose of $0 \mathrm{~kJ} \mathrm{~m}^{-2}$ of UV-C (Figures $1 \mathrm{~A}$ and 1C). This result may be related to the fact that the sweetness sensation, although important, is not the only 
responsible for the formation of flavor, which may be influenced by other substances that have undergone alterations due to UV-C irradiation treatment.

In the 'Trebbiano' juice, the initial sample had higher SS concentrations when compared to the dose of $0 \mathrm{~kJ} \mathrm{~m}^{-2}$ of UV-C (Table 1). These results agree with Detoni et al. (2005), who also found a decrease of SS in stored grapes. This reduction in SS content, observed in other studies, is associated with the use of sugars in the respiratory activity (COOMBE et al., 1992).

At the irradiation dose of $2 \mathrm{~kJ} \mathrm{~m}^{-2}$ for 'Trebbiano' cultivar, higher SS concentration was observed, when compared to the dose of $0 \mathrm{~kJ} \mathrm{~m}^{-2}$ of UV-C and a reduction in the concentration of total sugars (Table 1). In the ordering test carried out in the sensory analysis of this cultivar, it was observed that in samples treated with doses of 0,1 and $2 \mathrm{~kJ} \mathrm{~m}^{-2}$, there were no significant differences for color and aroma attributes $(\mathrm{p}<0.05)$ (Figure $1 \mathrm{~A}$ and $1 \mathrm{~B}$ ), and at the dose of $3 \mathrm{~kJ} \mathrm{~m}^{-2}$, samples presented lower intensity in both attributes. Bertagnolli et al. (2007), in a similar work, reported that wines from 'Trebbiano' cultivar elaborated from berries irradiated with UV-C showed greater acceptability, representing $56.66 \%$ of judges in attribute aroma.

A reduction of SS content, total sugars, total anthocyanins and total polyphenols was observed in treatments of 'Isabel' grapes with UV-C irradiation (Table 1). In spite of the reduction of total anthocyanins, it was observed in the ordination test $(p<0.05)$ that juices produced from irradiated berries obtained the highest intensity scores in attribute color (Figure 1A). In this ordering test, a significant increase in aroma $(p<0.05)$ was observed, especially in juices made from grapes treated with UV-C dose of $2 \mathrm{~kJ} \mathrm{~m}^{-2}$ (Figure 1B).

In the 'Cabernet Sauvignon' juice, it was observed from the initial analysis that the dose of $0 \mathrm{~kJ} \mathrm{~m}^{-2}$ of UV-C with five days storage, there was an increase in SS concentration, total acidity, nonreducing sugars and total polyphenols, possibly because in the postharvest period, the respiratory activity may have increased, consequently dehydrating berries and concentrating these compounds. During the storage period, a decrease in reducing sugars was also observed. This may indicate that there was consumption by metabolism for conversion to energy and production of polyphenols, since there was a 3.5 times increase in the concentration of total polyphenols (Table 1).

With UV-C irradiation, there was a decrease in the content of non-reducing sugars and an increase in reducing sugars (Table 1). This change in sugars was not observed in the ordering test, since there was no statistical difference $(p<0.05)$ in flavor attribute (Figure $1 \mathrm{C}$ ). However, a statistical difference $(p<0.05)$ in aroma attribute with dose of $2 \mathrm{~kJ} \mathrm{~m}^{-2}$ was observed, being referred to as "the most intense" when compared to UV-C dose of $0 \mathrm{~kJ} \mathrm{~m}^{-2}$ (Figure 1B).

Normative Instruction No. 01 of January 7, 2000 refers to the technical regulation that establishes identity and quality standards for grape juice. In the present study, juices made from grapes irradiated with UV-C presented concentrations of total sugars within values allowed by the Brazilian legislation, except for 'Cabernet Sauvignon' juices that remained with exceeding values $(23.9 \pm 1.1$ to $27.3 \pm 0.6 \mathrm{~g} 100$ $\mathrm{mL}^{-1}$ ), which could be explained by the fact that it is a cultivar with high oenological potential. Regarding total acidity, only 'Trebbiano' $(0.35 \pm 0.0$ to $0.40 \pm 0.0$ g $\left.100 \mathrm{~mL}^{-1}\right)$ and 'Cabernet Sauvignon' juices $(0.30 \pm$

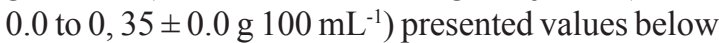
the minimum required. Regarding soluble solids, it was observed that 'Niagara Branca', 'Trebbiano' and 'Isabel' juices remained below values established by Normative Instruction No. 01 of 2000 , which determines minimum of $14^{\circ}$ Brix (Table 1). In the SS / TA ratio, it was observed that only 'Cabernet Sauvignon' juices $(62.3 \pm 2.4$ to $86.9 \pm 3.4)$ presented very high values according to Ordinance No. 55 of 2004 , indicating juices in sensory imbalance, being extremely sweet. 


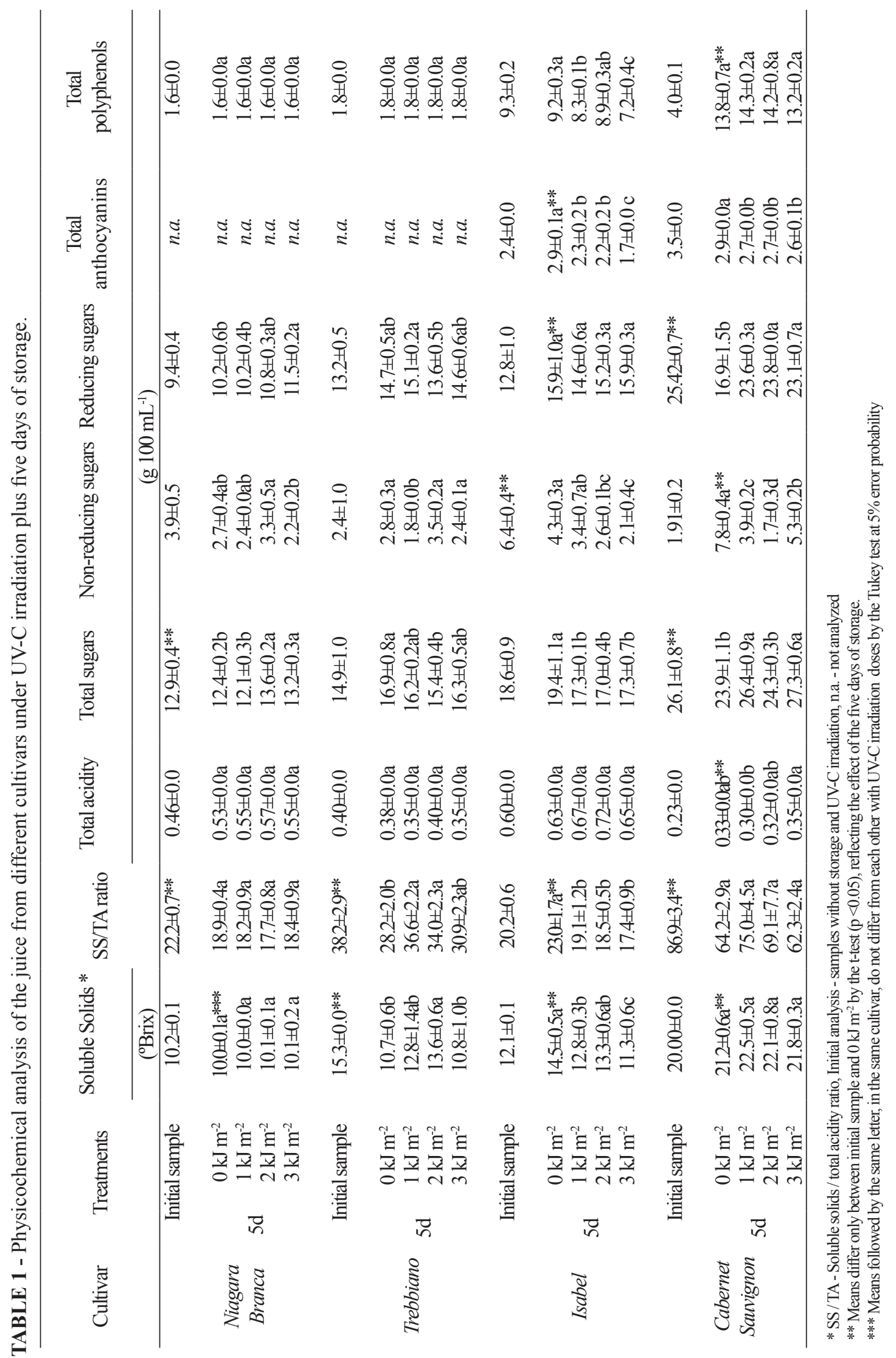




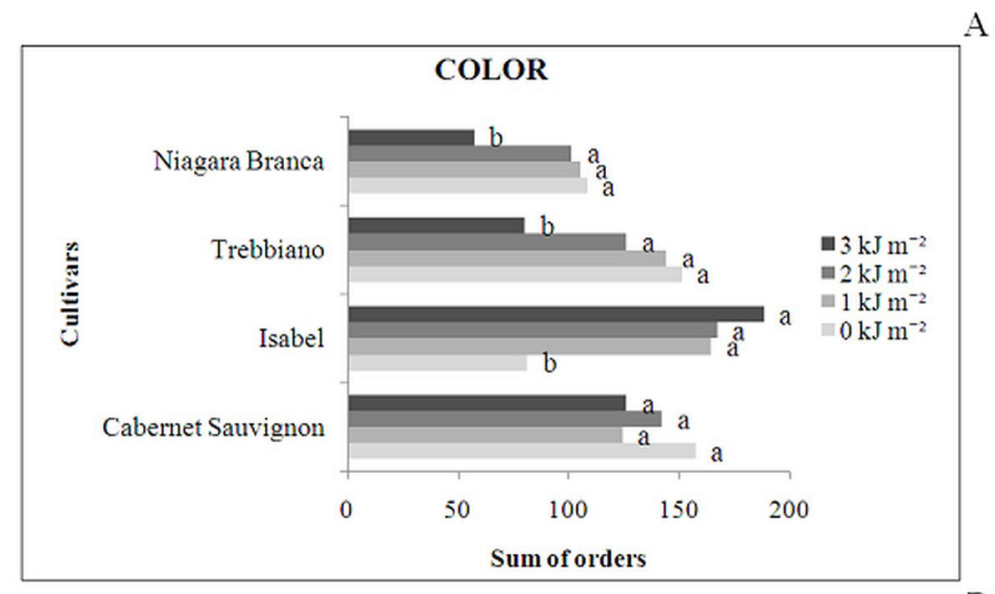

A
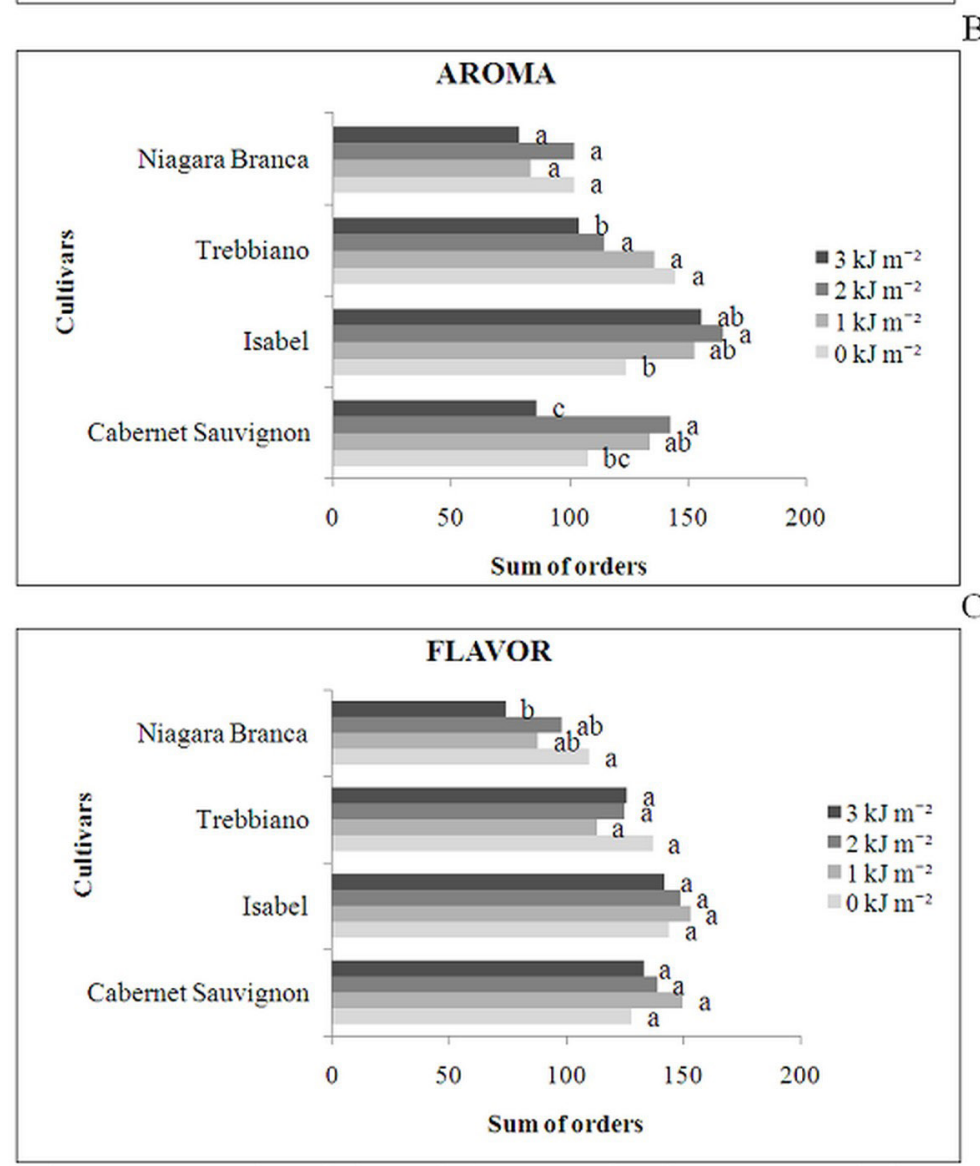

FIGURE 1 - Results of the ordering test of color (A), aroma (B) and flavor (C) parameters of juice from 'Niagara Branca', 'Trebbiano', 'Isabel' and 'Cabernet Sauvignon' grapes submitted to different doses of UV-C irradiation. 1Means followed by the same letter, in the same cultivar, do not differ from each other with UV-C irradiation doses by the Friedman test and the Newell and MacFarlane table at 5\% error probability. 


\section{CONCLUSION}

The storage period and irradiation promoted few physicochemical changes in juices from 'Niagara Branca' and 'Trebbiano' grapes, whereas sensorially, irradiation reduced the intensity of flavor and color attributes for both cultivars, demonstrating that treatment with UV-C irradiation contributes little to the improvement of juices made from white grapes.

In juice from red grapes, the storage period concentrated sugars in both cultivars. UV-C irradiation influenced the physicochemical parameters of each cultivar distinctly, with 'Isabel' being more sensitive to treatment. The dose of $2 \mathrm{~kJ}$ $\mathrm{m}^{-2}$ increases the aroma intensity in red grapes, with the highest color intensity for 'Isabel' juice.

UV-C irradiation is an alternative technology capable of improving some sensory attributes of red grape juices. However, there were few positive changes in the physicochemical aspects, and further studies are needed to elucidate the influence of UV-C irradiation, mainly on phenolic and volatile characterization and composition.

\section{ACKNOWLEDGMENTS}

The authors would like to thank the "Almadén" and "Velho Amâncio" wineries and CNPq, CAPES and FAPERGS for the financial support and the granting of scholarships.

\section{REFERENCES}

ALI, K.; MALTESE, F.; CHOI, Y. H.; VERPOORTE, R. Metabolic constituents of grapevine and grapederived products. Phytochemistry Reviews, Dordrecht, v.9, n.3, p.357-378, 2010.

AMERINE, M. A.; OUGH, C. S. Wine and must analysis. New York: J. Wiley \& Sons, 1980. 121p.

ANDROUTSOPOULOS, V.P.; PAPAKYRIAKOU, A.; VOURLOUMIS, D.; TSATSAKIS, A.M.; SPANDIDOS, D. A. Dietary flavonoids in cáncer therapy and prevention: substrates and inhibitors of cytochrome P450 CYP1 enzymes. Pharmacology \& Therapeutics, Oxford, v.126, n.1, p.9-20, 2010.
BERTAGNOLLI, S. M. M.; ROSSATO, S. B.; SILVA, V.L.; CERVO, T.; SAUTTER, C. K.; HECKTHEUER, L. H. R.; PENA, N.G. Evaluación físico-química y análisis sensorial envinos tinto $\mathrm{y}$ blancoproducidos através de diferentes técnicas de vinificación. Alimentaria, Bogotá, v.100, 99-106, 2007.

BRASIL. Leis, Decretos, etc. Instrução Normativa $\mathrm{n}^{\circ} 1$, de 7 janeiro de 2000. Aprova os Regulamentos Técnicos para fixação dos padrões de identidade e qualidade para polpas e sucos de frutas. Diário Oficial da União, Brasília, DF, 10 jan.2000. Seção 1, p.54-58.

BRASIL. Portaria n ${ }^{0} 55$, de 27 de julho de 2004. Normas referentes à complementação dos padrões de identidade e qualidade do vinho e dos derivados da uva e do vinho. Disponível em: $\leq \mathrm{http}: / / \mathrm{www}$. agricultura.gov.br/legislacao $>$. Acesso em: 25 set. 2015.

CAMARGO, U. A.; MAIA, J. D. G.; RITSCHEL, P.S. Novas cultivares brasileiras de uva. Bento Gonçalves: Embrapa Uva e Vinho, 2010. 64 p.

CANTOS, E.; ESPÍN, J. C.; TOMÁS-BARBERÁN, F.A. Postharvest stilbene-enrichment of Red and White Table Grape Varieties using UV-C irradiation pulses. Journal of Agricultural and Food Chemistry, Easton, v.50, p.6322-6329, 2002.

ÇETIN, E.S.C., ALTINOZ, D., TARC, E., BAYDAR, N.G. Chemical composition of grape canes. Industrial Crops and Products, Amsterdam, v.34, p.994-998, 2011.

COOMBE, B.G. Research on development and ripening of the grape berry. American Journal of Enology and Viticulture, Davis, v.43, n.1, p.101110, 1992.

DETONI, A. M.; CLEMENTE, E.; BRAGA, G. C.; HERZOG, N.F. M. Uva "Niágara Rosada" cultivada no sistema orgânico e armazenada em diferentes temperaturas. Ciência e Tecnologia de Alimentos, Campinas, v25, n.3, p.546-552, 2005.

DI STEFANO, R.; CRAVERO, M.C.; GENTILINI, N. Metodi per lostudio dei polifenoli dei vini. L'Enotecnico, Milano,v.25, p.83-89, 1989. 
DUTRA, M. C. P.et al. Influência da variedade de uvas nas características analíticas e aceitação sensorial do suco artesanal. Revista Brasileira de Produtos Agroindustriais, Campina Grande, v.16, n.3, p.265-272, 2014.

IAL - Instituto Adolfo Lutz. Análise sensorial: métodos físico-químicos para análise de alimentos. 4. ed. São Paulo: IAL, 2008. 1020 p.

IBRAVIN - Instituto Brasileiro do Vinho. Pesquisa mapeia hábitos de consumo do suco de uva $100 \%$. 2015. Disponível em: <http://www.ibravin.org.br/ noticias/245.php $>$. Acesso em: 4 jun. 2016.

MANFROI, V. Elaboração de sucos de uva. Especialização por tutoria à distância. Porto Alegre: ABEAS/UFRGS,1999. p.25-31 (Curso de Vitivinicultura).

MARTI, G.; SCHNEE, S.; ANDREY, Y.; SIMOESPIRES, C.; CARRUPT, P.A.; WOLFENDER, J. L.; GINDRO, K. Study of leaf metabolomemodifications induced by UV-C radiations in representative Vitis, Cissus and Cannabis species by LC-MS based metabolomicsand antioxidant assays. Molecules, Paris, v.19, p.14004-14021, 2014.

MEILGAARD, M.; CIVILLE, G. V.; CARR, B. T. Sensory evaluation techniques. Flórida: CRC Press, 1987.

NELSON, N.A photometric adaptation of the Somogyi method for the determination of glucose. Journal of Biological Chemistry, Baltimore, v.153, p.375-380, 1944

PALA, Ç.U.; TOKLUCU, A.K. Effects of UV-C light processing on some quality characteristics of grape juices. Food and Bioprocess Technology, Amsterdam, v.6, n.3, p.719-725, 2013.

PINTO, E. P; PERINA, E. C.; SCHOTT, I. B.; RODRIGUES, R. S.; LUCCHETTA, L.; MANFROI, V.; ROMBALDI, C. V.The effect of postharvest application of UV-C radiation on the phenolic compounds of conventional and organic grapes (Vitislabrusca cv. 'Concord'). Postharvest Biology and Technology, New York, v.120, p.84-91, 2016.

RUIZ, R. B.; HERNÁNDEZ, P.S. Diet and cancer: Risk factors and epidemiological evidence. Maturitas, Amsterdam, v.77, p.202-208, 2014.
SAUTTER, C. K., et al. Síntese de trans-resveratrol e controle de podridão em maçãs com uso de elicitores em pós-colheita. Pesquisa Agropecuária Brasileira, Brasília, DF, v.43, n.9, p.1097-1103, 2008.

SCHUMPP, O.; BRUDERHOFER, N.; MONOD, M.; WOLFENDER, J.L.; GINDRO, K. Ultraviolet induction of antifungal activity in plants. Mycoses, Berlin, v.55, p.507-513, 2012.

SHAMA, G.; ALDERSON, P. UV hormesis in fruits: a concept ripe for commercialization. Trends in Food Science \& Technology, Cambridge, v.16, p.128-136, 2005.

SHEN,Y.; SUN, Y.; QIAO, L.; CHEN, J.; LIU, D.; YE, X. Effect of UV-C treatments on phenolic compounds and antioxidant capacity ofminimally processed Satsuma mandarin during refrigerated storage. Postharvest Biology and Technology, New York, v.76, p. 50-57, 2013.

SINGLETON, V.L.; ROSSI JUNIOR, J.A. Colorimetry of total phenolics with phosphomolybdicphosphotungstic acid reagents. American Journal of Enology and Viticulture, Davis, v.16, p.144-158, 1965.

TANGNEY, C. C.; RASMUSSEN, H. E. Polyphenols, Inflammation, and Cardiovascular Disease. Current Atherosclerosis Reports, Philadelphia, v.15, n.324, p.1 -15, 2013.

TREPTOW, T. C. Irradiação UV-C em cultivares de uvas Niágara Branca, Trebbiano, Isabel e Cabernet Sauvignon. 2012. 82f. Dissertação (Mestrado em Ciência e Tecnologia dos Alimentos) - Universidade Federal de Santa Maria, Santa Maria, 2012.

TYUNIN, A. P.; KISELEV, K. V. Alternations in VaSTS gene cytosine methylation and t-resveratrol production in response to UV-C irradiation in Vitisamurensis Rupr. cells. Plant Cell, Tissue and Organ Culture, Dordrecht, v.124, p.33-45, 2016.

VERMERRIS, W.; NICHOLSON, R. Phenolic compound biochemistry. Dordrecht: Springer, 2006. 276p.

YAMAGATA, K.; TAGAMI, M.; YAMORI, Y. Dietary polyphenols regulate endothelial function and prevent cardiovascular disease. Nutrition, London, v.31, p.28-37, 2015. 